\title{
Tantangan Etika Layanan Nutrigenomik
}

\author{
Wiji Lestari ${ }^{\mathrm{I}}$, Gabriella Lonardy, Agus Purwadianto ${ }^{2,3}$ \\ 'Departemen Gizi Klinik, Fakultas Kedokteran Universitas Indonesia \\ ${ }^{2}$ Majelis Kehormatan Etik Kedokteran Pengurus Besar Ikatan Dokter Indonesia \\ ${ }^{3}$ Departemen Ilmu Kedokteran Forensik dan Medikolegal, Fakultas Kedokteran Universitas Indonesia/Rumah Sakit Cipto Mangunkusumo
}

\section{Kata Kunci \\ Etik, nutrigenomik \\ Korespondensi \\ wiji.lestarig9@ui.ac.id \\ Publikasi \\ (C) 2019 JEKI/ilmiah.id \\ DOI \\ 10.26880/jeki.v3i2.38}

Tanggal masuk: I8 Agustus 2019

Tanggal ditelaah: 2I Oktober 2019

Tanggal diterima: 25 November 2019

Tanggal publikasi: 30 Desember 2019
Abstrak Secara epidemiologis, penyakit tidak menular di Indonesia menempati angka tertinggi dan dampaknya pada finansial negara dapat terbilang katastropik. Penggunaan informasi genetik pada nutrigenomik ini berlandaskan konsep kedokteran ${ }_{4} \mathrm{P}$ (personalized, predictive, preventive, dan participatory) sehingga berpotensi untuk memotivasi individu untuk mengubah gaya hidup pola makan lebih baik, sebagaimana relevan dalam era JKN ini. Walaupun begitu, terdapat beberapa hal yang harus dipertimbangkan secara etis, yakni konfidensialitas dan privasi informasi genetik, biaya yang dibebankan kepada pasien, dampak psikologis dan stigmatisasi pada individu yang melalui pemeriksaan genetik diketahui memiliki kerentanan terhadap suatu penyakit, serta otonomi pada pemeriksaan anak. Di samping pertimbangan etik tersebut, perlu ditelaah dampaknya terhadap tata laksana pasien, yang mana dalam hal ini dominansi dampak dapat secara positif maupun negatif.

\begin{abstract}
Epidemiologically, non-communicable diseases in Indonesia are the highest in number and the impact on state finances not arguably are catastrophic. The use of genetic information on nutrigenomics is based on the concept of ${ }_{4} \mathrm{P}$ medicine (personalized, predictive, preventive, and participatory) and intends to motivate individuals to change their eating pattern and life style more effectively, not to mention in this JKN era. However, a number of things still in needs to be discussed, namely confidentiality and privacy of genetic information, costs given to patients, psychological evaluation and stigmatization of individuals who undergo genetic testing that are shown to be susceptible to certain diseases, and autonomy on examination of children. In addition to these ethical considerations, its impact on patient management needs to be explored, wherein positive or negative impacts can prevail over in which case.
\end{abstract}

Ilmu kedokteran masa kini telah memasuki era baru. Konsep kedokteran 4P: personalized, predictive, preventive, dan participatory berkembang tidak hanya untuk menata laksana sebuah penyakit namun juga memaksimalkan kesehatan individu. Hal ini didukung oleh munculnya data besar genomik manusia yang memuat informasi presisi tentang manusia dan prognostik medis ke depan. Personalisasi intervensi kedokteran mampu memberikan intervensi yang efektif, dirancang khusus berdasarkan profil genomik dan kultur masing-masing individu. Tidak hanya berbicara mengenai tata laksana, data genomik dapat memprediksi kerentanan penyakit dan memungkinkan langkah pencegahan spesifik. Kedokteran personal ini juga meningkatkan partisipasi pasien sebagai individu yang bertanggung jawab atas kesehatan dirinya sebagai simbol dari hak atas penentuan nasib sendiri. ${ }^{1,2}$ Secara agregat kumpulan dari individu tersebut akan menciptakan populasi yang matang secara bioetik sehingga memunculkan fenomena baru seperti berdayanya organisasi pasien dan model peradaban baru kelak.

Pemeriksaan genomik memiliki lingkup yang luas. Pemeriksaan genomik telah diintegrasikan pada pelayanan kesehatan dalam bentuk diagnostik dan skrining molekuler, deteksi penyakit, dan memampukan pemberian intervensi yang spesifik. Nutrigenomik merupakan salah satu area dari kedokteran gizi yang menggunakan informasi genetik untuk mencari dan mengevaluasi respon dari diet 
tertentu terhadap ekspresi gen pada individu tertentu. Terutama dalam rangka upaya mencari sisi hulu dari klaster penyakit tidak menular yang saat ini di Indonesia menempati urutan pertama secara epidemiologik, sekaligus menyumbangkan musibah katastropik terhadap perlindungan finansial rakyat suatu negara walaupun sudah memasuki era JKN. ${ }^{3}$ Nutrigenomik berperan dalam perancangan intervensi diet yang personal sehingga diharapkan dapat meningkatkan kesehatan dan mencegah penyakit tidak menular sehingga pemahamannya dapat berkontribusi secara makro untuk membebaskan Indonesia dari jebakan bonus demografik. Hasil pemeriksaan nutrigenomik dapat memotivasi individu untuk mengubah gaya hidup terkait pola makan yang dapat menentukan nasib kesehatannya di masa datang. ${ }^{4,5} \mathrm{Hal}$ ini sejalan dengan "You are what you eat". ${ }^{6}$

\section{Konfidensialitas dan privasi informasi genetik}

Untuk akurasi intervensi genomik termasuk nutrigenomik kita memerlukan kemutakhiran dari data besar yang berjalin berkelindan dengan artificial intelligence. Banyak data yang dikumpulkan mengandung rincian data individu melalui data elektronik terbaru yang bagi sebagian besar masyarakat di era media sosial saat ini tidak menyadari risiko dari dikumpulkannya secara agregat data mereka baik melalui lalu lintas data elektronik maupun pengambilan spesimen atau gabungan dari keduanya. Padahal data genetik merupakan informasi sensitif memuat seluruh informasi dan identitas seorang individu, sebagaimana tertera di dalam Universal Declaration of Human Genome and Human Rights dari UNESCO yang menyebutkan bahwa privasi individu tidak boleh dikorbankan dan justru harus dilindungi dan dihormati. ${ }^{7}$ Hal ini dikenal sebagai prinsip irretrievable unlinked sesuai dengan kaidah dasar otonomi. Pasien memiliki hak atas data genetik mereka sehingga mereka harus mendapatkan perlindungan data privasi mereka, yang diwujudkan dalam informed consent awal pada setiap hubungan hukum yang melibatkan diri mereka. Kemudian diikuti dengan senantiasa mendapat informasi yang jelas dan memberikan consent terhadap pemeriksaan genetik termasuk penggunaan data tersebut untuk kebutuhan sekunder (misalnya penelitian, penggunaan komersil) yang diwujudkan dalam permintaan persetujuan baru.

Penyalahgunaan informasi merupakan risiko data pribadi yang harus diperhatikan. Hendaknya keamanan data genetik diperlakukan sama seperti informasi medis dan dijaga kerahasiaannya sesuai dengan etik profesi kedokteran. Pasien seharusnya dapat mempercayai keamanan dari laboratorium, tenaga medis, dan fasilitas rekam medis. Dokter wajib merahasiakan segala sesuatu yang ia ketahui tentang pasien dari hubungan dokter-pasien, bahkan juga setelah pasien itu meninggal dunia sesuai dengan KODEKI pasal 16. Pasal ini juga mencakup kewajiban dokter untuk tidak memberikan pernyataan tentang diagnosis dan/atau pengobatan pasien kepada pihak ketiga dan masyarakat luas tanpa persetujuan pasien.

\section{Targeted gene vs genomic testing}

Pemeriksaan genomik meliputi seluruh sekuens genom dari individu, berbanding dengan pemeriksaan spesifik / targeted genetic testing. Pemeriksaan seluruh genom dapat menampilkan analisis komprehensif dari satu individu, dengan kelemahan berupa penemuan temuan sekunder yang awalnya tidak direncanakan, dan penemuan data-data yang tidak bermakna secara klinis. Pemeriksaan genetik sesuai indikasi klinis dapat dilakukan melalui analisis gen tunggal/single-gene analysis atau targeted gene testing. ${ }^{8}$ Pemeriksaan seluruh genom memakan biaya yang lebih besar dibandingkan pemeriksaan spesifik sehingga seorang dokter yang memperhatikan aspek nutrigenomik harus memiliki pertimbangan biaya yang harus ditanggung pasien (keluarganya) dibandingkan dengan keuntungan klinis baik diagnosis maupun terapi yang akan didapatkan.

\section{Dampak psikologis dan stigma}

Salah satu perhatian atas pemeriksaan genomik adalah dampak psikologis pada individu yang diketahui memiliki kerentanan 
terhadap suatu penyakit dan stigma masyarakat yang menyertainya. Pertimbangan lain pemeriksaan genomik adalah kemungkinan labelling yang memengaruhi faktor psikologis pasien khususnya anak atau yang rentan dan kemungkinan diskriminasi yang dihadapinya terkait pola makan seperti misalnya pembatasan/keharusan diet. Pembukaan hasil pemeriksaan genomik berpotensi menghasilkan dampak psikologis dan kecemasan kepada klien dan keluarga. KODEKI pasal 5 membahas tentang perbuatan atau nasihat dokter yang mungkin melemahkan psikis. Risiko dampak psikologis perlu disampaikan kepada klien dan keluarganya sebelum dilakukan pemeriksaan genomik. Dokter juga memiliki kewajiban untuk menghormati keinginan pasien untuk menolak mendapatkan informasi (waiver) mengenai hasil pemeriksaan setelah menjelaskan informasi mengenai risiko tersebut.

Nilai prediktif informasi genomik bersifat prognostik berdasarkan data empiris penelitian yang sudah ada dan bersifat probabilitas. Kondisi medis dipengaruhi oleh interaksi gen dan lingkungan sehingga kerentanan genetik belum pasti akan menghasilkan kondisi medis terkait. Oleh karena itu, dokter perlu berhatihati dalam menginterpretasi hasil pemeriksaan, khususnya kepada orang-orang yang tidak berkapasitas sepenuhnya (contohnya anak-anak dan lansia).

Terbukanya hasil pemeriksaan kepada masyarakat karena kurang hati-hati dari dokter ataupun staff analisis mungkin menimbulkan stigma bagi pasien dan keluarganya. Harus diingat bahwa kondisi medis berdasarkan pemeriksaan genomik tersebut masih berpotensi menambah kerentanan. Diperlukan edukasi kepada pasien agar pasien sadar akan kerentanan tersebut, sehingga tidak menimbulkan kecemasan berlebihan.

\section{Pemeriksaan direct-to-consumer}

Pemeriksaan genomik Direct-to-Costumer (DTC) bermunculan seiring dengan utilisasi pemeriksaan genomik dalam kedokteran. Pemeriksaan DTC dipasarkan kepada konsumen dan memungkinkan akses langsung tanpa perantara tenaga medis. Tidak adanya konseling pre-test dan post-test oleh tenaga medis yang kompeten dapat menimbulkan misinformasi, disinformasi, dan interpretasi data yang keliru. Dokter khususnya spesialis gizi klinik memiliki peran melakukan edukasi terhadap kepentingan terbaik pasien dan keluarganya beserta costbenefit pemeriksaan nutrigenomik tersebut.

\section{Pemeriksaan genomik pada anak}

Pemeriksaan genomik pada pasien anak menimbulkan isu otonomi anak dalam mengambil keputusan untuk menjalani pemeriksaan sebab hasil pemeriksaan memiliki implikasi kepada masa depan anak tersebut. Anak dianggap belum berkapasitas dalam pengambilan keputusan sehingga hak tersebut dialihkan kepada orang tua, dengan harapan pemeriksaan tersebut memang dilakukan untuk kepentingan anak. Jika pemeriksaan tidak memiliki indikasi klinis yang mendesak, pemeriksaan dapat ditunda hingga usia dewasa. ${ }^{8}$

\section{Implikasi terhadap tata laksana pasien}

Perkembangan nutrigenomik dan personalised nutrition menantang penerapan rekomendasi nutrisi dari sisi kesehatan masyarakat. Intervensi nutrisi dari kesehatan masyarakat bertujuan untuk mempromosikan gaya hidup sehat dan memenuhi kebutuhan nutrisi dari sebagian besar orang di populasi sehingga dibentuk pedoman berbasis populasi. Penelitian nutrigenomik menunjukkan bahwa konsep "one size fits all" tidak dapat digeneralisir kepada setiap orang. Sebagai contoh, terdapat single nucleotide polymorphism (SNP) MTHFR yang bekerja pada metabolisme folat. Individu dengan alel homozigot yang telah bermutasi membutuhkan asupan asam folat yang lebih besar untuk mencegah defisiensi. Kelompok individu ini membutuhkan asupan folat di atas nilai angka kecukupan gizi yang diterapkan dalam pedoman kesehatan masyarakat. Contoh lain adalah polimorfisme pada gen APOA1 di mana individu dengan alel $\mathrm{A}$ menunjukkan peningkatan kolesterol HDL setelah konsumsi polyunsaturated fatty acids (PUFA), berbeda dengan individu dengan alel $G$ yang justru mengalami penurunan HDL. Beberapa temuan ini menunjukkan adanya perbedaan saran 
nutrisi yang dapat diberikan kepada seorang individu. ${ }^{9}$

\section{KESIMPULAN}

Informasi genetik merupakan data prediktif bermakna untuk masa depan seorang individu sehingga diperlukan pengolahan informasi yang sesuai. Seorang dokter secara normatif mengambil keputusan klinis dengan pertimbangan rasional berdasarkan aspek biomedis dan bioetik sekaligus secara deskriptif berdasarkan nilai empati dan etika. Keputusan klinis untuk melakukan pemeriksaan genomik memerlukan integrasi antara ilmu biomedik, bioetik, dan kedokteran untuk kepentingan pasien. Dalam mengumumkan layanan nutrigenomik ini juga perlu memperhatikan kaidah etika sehingga tidak beriklan berlebihan ${ }^{10}$, dan jika menggunakan media sosial juga perlu berhati-hati dalam memberikan informasi melalui akun dengan pertemanan khusus. ${ }^{11}$

\section{KONFLIK KEPENTINGAN}

Tidak ada konflik kepentingan.

\section{REFERENSI}

1. Hood L, Friend SH. Predictive, personalized, preventive, participatory (P4) cancer medicine. Nat. Rev. Clin. Oncol. 2011;8:184. https://doi.org/10.1038/nrclinonc. 2010.227

2. Mathur S, Sutton J. Personalized medicine could transform healthcare. Biomed Rep. 2017;7(1):3-5 doi:10.3892/br.2017.922

3. Purnamasari D. The emergence of non-communicable disease in Indonesia. Acta Med Indonesia. 2018 Oct;50(4):273-4

4. Sales NMR, Pelegrini PB, Goersch MC. Nutrigenomics: definitions and advances of this new science. J Nutr Metab. 2014:1-6. https://doi.org/10.1155/2014/202759
5. Pavlidis, Patrinos GP, Katsila T. Nutrigenomics: a controversy. Appl Transl Genom. 2015:50. https://doi.org/10.1016/j. atg.2015.02.003

6. Mead MN. Nutrigenomics: the genome-food interface. Environ Health Perspect. 2007 Dec;115(12). https://doi. org/10.1289/ehp.115-a582

7. Universal Declaration on the Human Genome and Human Rights: UNESCO [Internet]. [cited 2019 Jul 14]. Available from: http://portal.unesco.org/en/ev.phpURL_ID $=13177 \& U R L \_D O=D O \_T O P$ IC\&URL_SECTION=201.html

8. Botkin JR, et al. Points to consider: ethic, legal, and psychosocial implications of genetic testing in children and adolescents. Am J Hum Genet. 2015;97(3):6-17. https:// doi.org/10.1016/j.ajhg.2015.05.022.

9. Kohlmeier M, et al. Guide and position of the international society of nutrigenetics/ nutrigenomics on personalized nutrition: part 2 - ethics, challenges, and endeavors of precision nutrition. J Nutrigenet $\mathrm{Nu}$ trigenomics. 2016;9:28-46. https://doi. org/10.1159/000446347

10. Prawiroharjo P, Meilia PDI. Dokter beriklan: Sebuah tinjauan menurut Kode Etik Kedokteran Indonesia (KODEKI) tahun 2012. JEKI. 2017;1(1):13-7.. https:// doi.org/10.26880/jeki.v1i1.4.

11. Prawiroharjo P, Libritany N. Tinjauan etika penggunaan media sosial oleh dokter. JEKI. 2017;1(1):31-4. https://doi. org/10.26880/jeki.v1i1.7. 